\title{
Position Statements
}

A position statement is an official point of view or belief of the ADA. Position statements are issued on scientific or medical issues related to diabetes. They may be authored or unauthored and are published in ADA journals and other scientific/medical publications as appropriate. Position statements must be reviewed and approved by the Professional Practice Committee and, subsequently, by the Executive Committee of the Board of Directors. ADA position statements are typically based on a technical review or other review of published literature. They are reviewed on an annual basis and updated as needed. Listed below are recent position statements.

\section{Nutrition}

Diabetes Care 31 (Suppl. 1):S61-S78, 2008

\section{Generic Drugs}

Diabetes Care 30:173, 2007

Pancreas and Islet Transplantation in Type 1 Diabetes

Diabetes Care 29:935, 2006

Metabolic Syndrome

Diabetes Care 28:2289, 2005

\section{Neuropathy}

Diabetes Care 28:956, 2005

Children and Adolescents With Type 1 Diabetes

Diabetes Care 28:186, 2005

Dietary Carbohydrate

Diabetes Care 27:2266, 2004

Weight Management

Diabetes Care 27:2067, 2004

Unproven Therapies

Diabetes Care 27 (Suppl. 1):S135, 2004

Prevention of Type 1 Diabetes

Diabetes Care 27 (Suppl. 1):S133, 2004
Concurrent Care

Diabetes Care 27 (Suppl. 1):S132, 2004

Influenza and Pneumococcal Immunization in Diabetes

Diabetes Care 27 (Suppl. 1):S111-S113, 2004

\section{Continuous Subcutaneous Insulin} Infusion

Diabetes Care 27 (Suppl. 1):S110, 2004

\section{Insulin Administration}

Diabetes Care 27 (Suppl. 1):S106-S109, 2004

Pancreas Transplantation in Type 1

Diabetes

Diabetes Care 27 (Suppl. 1):S105, 2004

Bedside Blood Glucose Monitoring in Hospitals

Diabetes Care 27 (Suppl. 1):S104, 2004

Hospital Admission Guidelines for Diabetes

Diabetes Care 27 (Suppl. 1):S103, 2004

Hyperglycemic Crises in Diabetes Diabetes Care 27 (Suppl. 1):S94-S102, 2004

Tests of Glycemia in Diabetes

Diabetes Care 27 (Suppl. 1):S91-S93, 2004

Gestational Diabetes Mellitus

Diabetes Care 27 (Suppl. 1):S88-S90, 2004

Retinopathy in Diabetes

Diabetes Care 27 (Suppl. 1):S84-S87, 2004

Nephropathy in Diabetes

Diabetes Care 27 (Suppl. 1):S79-S83, 2004
Preconception Care of Women With Diabetes

Diabetes Care 27 (Suppl. 1):S76-S78, 2004

Smoking and Diabetes

Diabetes Care 27 (Suppl. 1):S74-S75, 2004

Aspirin Therapy in Diabetes

Diabetes Care 27 (Suppl. 1):S72-S73, 2004

Dyslipidemia Management in Adults With Diabetes

Diabetes Care 27 (Suppl. 1):S68-S71, 2004

Hypertension Management in Adults With Diabetes

Diabetes Care 27 (Suppl. 1):S65-S67, 2004

Preventive Foot Care in Diabetes Diabetes Care 27 (Suppl. 1):S63-S64, 2004

Physical Activity/Exercise and Diabetes

Diabetes Care 27 (Suppl. 1):S58-S62, 2004

\section{Diabetes Nutrition}

Recommendations for Health Care Institutions

Diabetes Care 27 (Suppl. 1):S55-S57, 2004

Prevention or Delay of Type 2

Diabetes

Diabetes Care 27 (Suppl. 1):S47-S54, 2004

Screening for Type 2 Diabetes

Diabetes Care 27 (Suppl. 1):S11-S14, 2004 